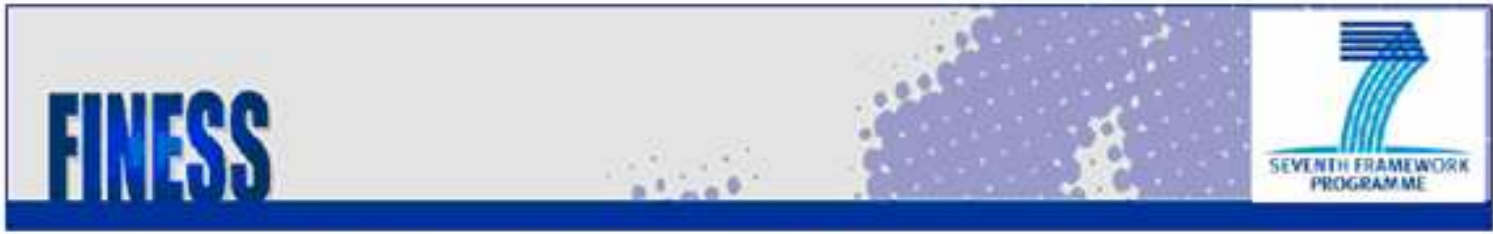

Project funded under the Socio-economic Sciences and Humanities

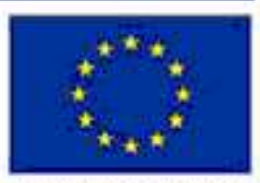

Working Paper D 5.6.

Eurogean Commiseion

Drivers of exchange rate dynamics in selected CIS countries: Evidence

$$
\text { from a FAVAR analysis* }
$$

Christian Dreger (German Institute of Economic Research, DIW Berlin)

Jarko Fidrmuc (University of Munich, ifo)

September 2009 


\title{
Drivers of exchange rate dynamics in selected CIS countries: Evidence
}

\author{
from a FAVAR analysis*
}

\author{
Christian Dreger ${ }^{\dagger}$, \\ Jarko Fidrmuc
}

\begin{abstract}
We investigate the likely sources of exchange rate dynamics in selected CIS countries (Russia, Kazakhstan, Ukraine, Kyrgyzstan, Azerbaijan, and Moldova) over the past decade (1999-2008). The analysis is based on country VAR models augmented by a regional common factor structure (FAVAR model). The models include nominal exchange rates, the common factor of exchange rates in the CIS countries, and global drivers such as gold, oil and share prices. Global, regional and idiosyncratic shocks are identified in a standard Cholesky fashion. Based on the decomposition of the variance of forecast errors, their relevance for exchange rates is explored. As a quite robust finding, CIS exchange rates have become more vulnerable to global shocks towards the end of the sample.
\end{abstract}

Keywords: Exchange rates, CIS countries, financial crisis, FAVAR models

JEL Classification: F31, C22, G15

\footnotetext{
* We appreciate valuable comments by Konstantin A. Kholodilin. The research leading to these results has received funding from the European Community's Seventh Framework Programme (FP7/2007-2013) under grant agreement number 217266: Financial systems, efficiency and stimulation of sustainable growth.

${ }^{\dagger}$ German Institute for Economic Research (DIW) and Institute for the Study of Labour (IZA), e-mail: cdreger@diw.de. Post address: Mohrenstraße 58, D-10117 Berlin, Germany.

${ }^{\ddagger}$ University of Munich, Department of Economics; CESifo Institute Munich; and Comenius University Bratislava, Slovakia Institute of Applied Mathematics and Statistics, e-mail: jarko.fidrmuc@lrz.uni-muenchen.de. Post address: Department of Economics, University of Munich, Geschwister-Scholl-Platz 1, 80539 Munich, Germany.
} 


\section{Introduction}

The countries of the Commonwelth of Intependent States (CIS) represent a very heterogeneous group of transition economies. The overall development is dominated by Russia (see Mayes and Korhonen, 2007). It accounts for almost 75 percent of nominal US dollar GDP and 50 percent of the population of the entire region. At the lower edge, some small states like Kyrgyzstan and Moldova have an output share of less than 1 percent. Despite the frequent critique, Russia is also the leading reformer in the region (Shleifer and Treisman, 2005), influencing possibly the economic policies in other CIS counries also by its conduct of reforms. Although the region seems to be dominated by the Russian economy, earlier papers show a surprisingly low role of regional factors. Both Chaplygin, Hughes and Richter (2006) and Shiells, Pani and Jafarov (2005) find a low degree of business cycle correlations in the region. Thus the level of trade integration remains low since the break-up of the Soviet Union (Fidrmuc and Fidrmuc, 2000). Moreover, Tiffin (2008) notes that also the level of financial integration in the region is below expectations. Nevertheless, Fungáčová and Solanko (2008) have noted that Russia intends to become a global financial center, as stated by e.g. the Russian president Medvedev as a goal of Russian economic policy in spring 2008. However, achievements in this field suffered significant losses during the financial crisis since the second half of 2008 .

Russia and some other countries of the region are also well equipped with natural resources (oil, gas and minerals). Behind this, Russia is generally found not to be deeply integrated to the world economy (Koźluk, 2008, Korhonen and Mehrotra, 2009). Similar evidence for other CIS countries is largely not available.

In recent years, the boom in world demand exerted a strong upward pressure on GDP growth, implying a faster catching up towards the per capita income of industrialized countries. As a rule, this process was accompanied by an appreciation of exchange rates (see Figure 1) and an accumulation of foreign reserves. 
Figure 1: Exchange rate of selected CIS countries (local currency per USD)
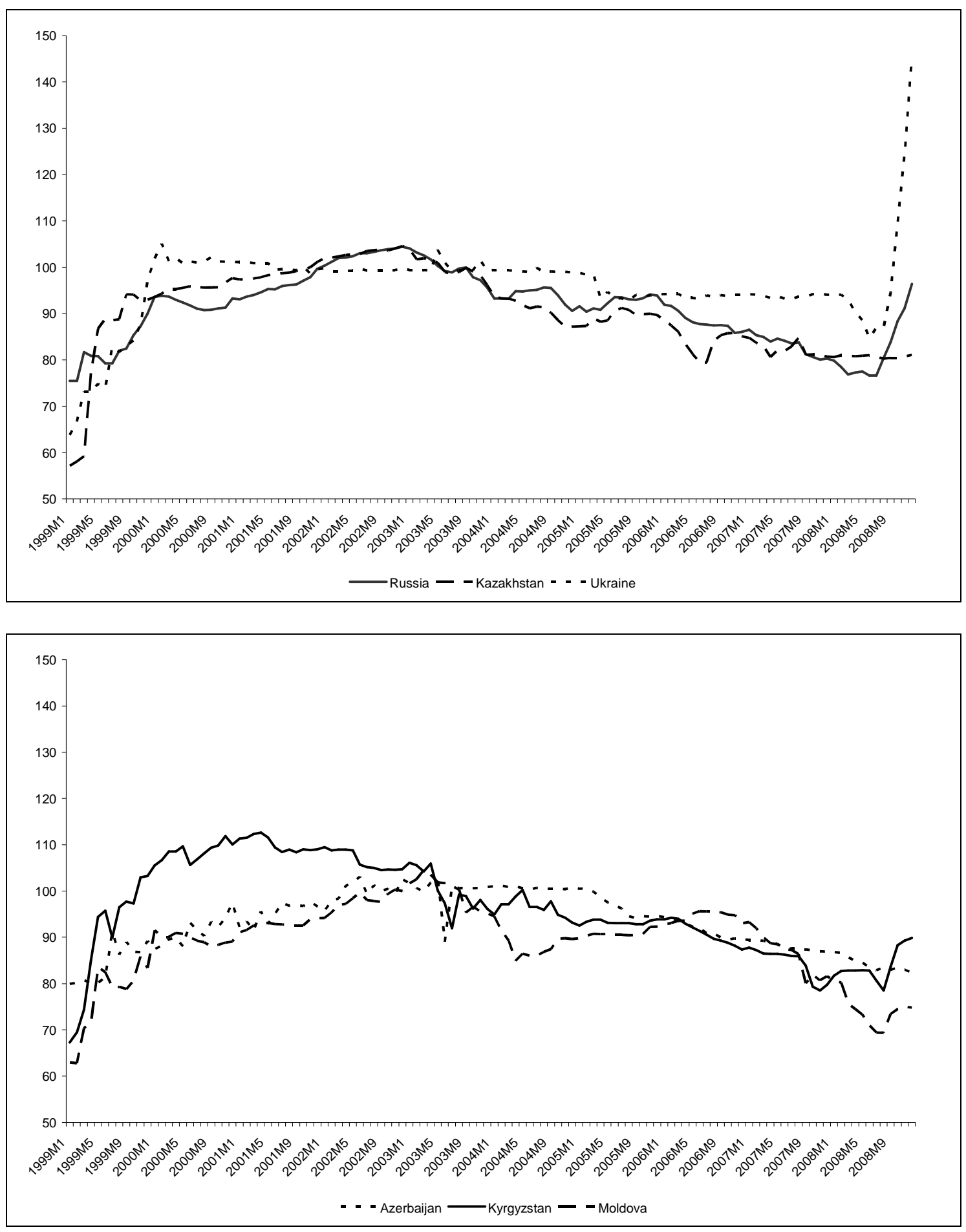

Source: IMF, own calculations. 
Starting in 2002, more or less, both the Azerbaijani Manat and the Kazakh Tenge appreciated by 20 percent against the US Dollar. Higher exports of raw materials and soaring inflows of foreign investment raised demand for the CIS currencies, which caused concerns whether this appreciation is sustainable or related to the Dutch-Disease phenomenon (Oomes and Kalcheva, 2007, and Égert and Leonard, 2008, Polterovich, Popov and Tonis, 2008). Actually, the appreciation of the CIS rates came to a halt and has even reversed over the recent months. Most spectacular, Ukrainian Hryvnia lost nearly 70 percent of its value between August and December 2008. But also the Russian Rouble, which improved against the US dollar by 30 percent until the mid of 2008, has lost 25 percent during the recent financial crisis. Lower prices for raw materials, slower global growth and tighter liquidity conditions due to the financial crisis have exerted a significant downward pressure on many CIS currencies. A further depreciation raises inflation with negative effects on financial stability in the short-run, although long-term growth prospect remain largely positive in the region.

To gain further insights into this process, we explore the likely sources of exchange rate dynamics in selected CIS countries (Russia, Kazakhstan, Ukraine, Kyrgyzstan, Azerbaijan, and Moldova) over the past decade (1999-2008), that is, after the Russian financial crisis in 1998.1 All countries have flexible exchange rate system. Evidence is built upon a FAVAR (factor augmented VAR) model. Country specific models include nominal exchange rates, the common factor of exchange rates in the CIS countries, and global drivers. Global, regional and idiosyncratic shocks are identified in a standard Cholesky fashion. In this framework, the relative importance of idiosyncratic (national), regional, and global shocks on exchange rates is explored. According to the variance decomposition of forecast errors, global shocks have become increasingly important in the second half of the sample, reflecting the vast integration of the CIS countries towards the world economy. In contrast, the relevance of regional shocks seems to have decreased over the recent years. Overall, the results reflect a higher integration in the world economy, implying that many CIS countries have become more vulnerable to external shocks. These findings are rather robust to changes in the model specification. In particular, they hold irrespectively of the concrete measure of global shocks, where gold, oil and stock market prices are considered.

\footnotetext{
${ }^{1}$ Schnabl (2005) has compared exchange rate stabilization before and after the Russian crisis of 1998. Korhonen and Wachtel (2006) present an analysis of the exchange rate pass-through of CIS countries between 1998 and
} 2004. 
The paper is organized in several sections. The econometric framework is reviewed in the next section (section 2). Section 3 presents the data and the empirical results. The final section (section 4) offers some conclusions.

\section{The FAVAR model}

The drivers of exchange rates are explored in a FAVAR framework. The VAR model is a convenient tool to study the dynamic interactions that drive the evolution of nominal exchange rates. The basic VAR specification, however, is extended by a common factor structure to proxy the regional element in the CIS exchange rates. This is recommended for two reasons. First, a large variable set can be compressed by the factor approach. Second, the regional element can affect exchange rates not only with a delay, but also in a contemporaneous way. In this sense, the common factor relieves the identification of regional shocks.

In particular, the regional variable is obtained as the principal component of the residuals from a first step VAR regression. At this stage, individual exchange rates are regressed on own lags, and lagged exchange rates from the other countries. Hence, the model is given by

$$
\begin{aligned}
& y_{t}=a(L) y_{t-1}+u_{t} \\
& u_{t}=\Gamma f_{t}+\varepsilon_{t}
\end{aligned}
$$

where $\mathrm{y}$ is the $5 \mathrm{x} 1$ vector of nominal exchange rates, and $\mathrm{a}(\mathrm{L})$ is a $(5 \times 5)$ matrix polynomial in the lag operator. The VAR errors $\mathrm{u}$ follow a common factor structure, where $\mathrm{f}$ is the (kx5) matrix of $\mathrm{k}$ common regional factors, $\Gamma$ is a (5xk) matrix of factor loadings, and $\varepsilon$ is a vector of idiosyncratic shocks.

After constructing regional factors, country individual VAR models are estimated to explain the importance and structure of nominal shocks for the exchange rates (Clarida and Galí, 1994, and Kutan and Dibooglu, 2001). They are built upon three variables, i.e. a global variable (g), the regional common factor (f) and the country exchange rate (s). The shocks are exactly identified in a triangular fashion by using the Cholesky decomposition. Due to the ordering ( $\mathrm{g}, \mathrm{f}, \mathrm{s}$ ), a global shock is allowed to affect all variables in a contemporaneous way. While the regional shock has an immediate impact on the national evolution, the latter can affect the region only with a delay. Then, inference can be conducted on the basis of a decomposition of the h-step ahead forecast error for the exchange rate. In particular, its variance can be traced to global, regional and idiosyncratic shocks. Since these fractions are orthogonal by construction, 
they sum of to 1 . Hence, the relative contribution of the various shocks to the forecast error variance can be interpreted as a percentage.

\section{Data and results}

The evidence is based on end of month data for nominal exchange rates against the US Dollar over the 1999.01 to 2008.12 period, that is after the Russian financial crisis (Odling-Smee, 2006). Six currencies are included in the analysis. The Rouble (Russia), the Tenge (Kazakhstan), the Hryvnia (Ukraine), the Som (Kyrgyzstan), the Manat (Azerbaijan) and the Leu (Moldova).2 To control for trends arising from the global economy, gold and oil prices are considered, both expressed in US Dollar. Moreover, the Dow Jones industrial index proxies the evolution in the international stock markets. All data are taken from the International Financial Statistics of the IMF. To obtain insights into possible changing patterns in the process of economic integration, the sample is splitted into two halves, i.e. 1999.01-2003.12 and 2004.012008.12. This reflects also different conditions especially in the Russian economy. For example, oil prices increased singinificantly since 2003 (Borkó, 2007). Both periods are characterized by approximately the same volatility of exchange rates (see Figures 1 and 2). However, the volatile observations are at the beginning of the first sub-sample (that is, in the first half of 1999) and at the end of the second sub-sample (in the second half of 2008).

The first step is to construct the common regional factor. At this stage, a VAR model is estimated for the CIS exchange rates. According to Sims, Stock and Watson (2002) and Juselius (2007), it is specified in levels to capture possible cointegration relationships between the variables involved. According to the Schwarz Bayesian information criterion, a lag length equal to 1 is the optimal choice. Then, a principal component is extracted from the VAR residuals. Due to the information criteria provided by Bai and $\mathrm{Ng}$ (2002), the first two principal components seem to be appropriate. They represent almost 60 percent of the overall variance of exchange rates in the first subsample, and 50 percent in the second period. Thus, the relevance of regional components seems to have decreased over the recent years, i.e. the currencies have become more differentiated. In order to avoid identification problems in further steps, a unique regional factor has to be preferred. It is defined as a linear combination of the first two principal components (see

\footnotetext{
${ }^{2}$ We exclude Belarus as it has a relatively closed financial sector dominated by state-owned banks (IMF, 2009). Furthermore, the exchange rates are pegged to the USD.
} 
Figure 2). The weights in the linear combination sum up to unity and are constructed due to the corresponding eigenvalues, i.e. the first principal component receives a weight of two third. However, the empirical results are almost identical, when the analysis is done only with the first principal component. Between 2004 and 2008, the CIS factor declined until August 2008, then it peaked up in October 2008, and declined again afterwards.

Figure 2: CIS factor

\section{Sample 1999 to 2003}

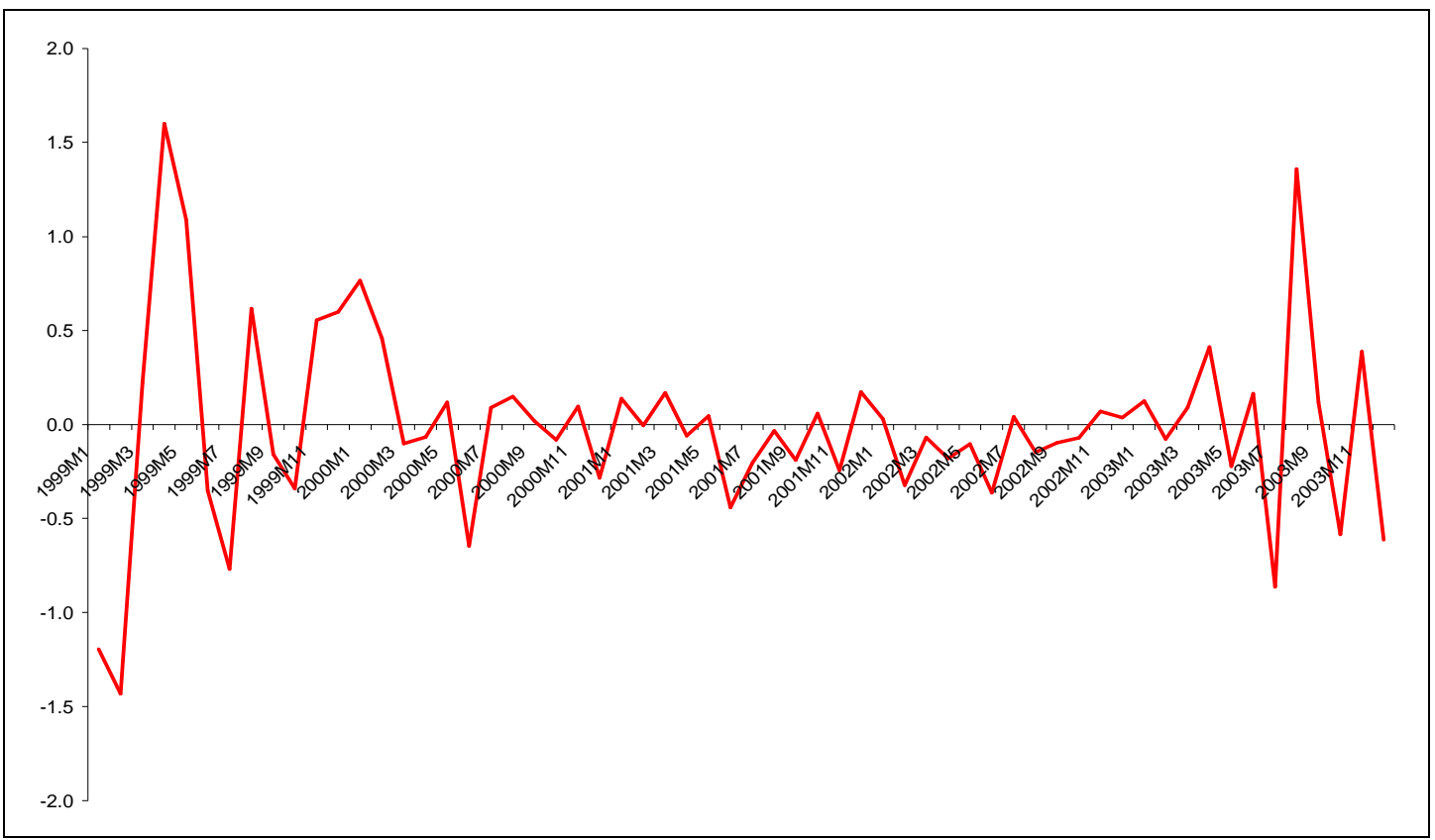

\section{Sample 2004 to 2008}

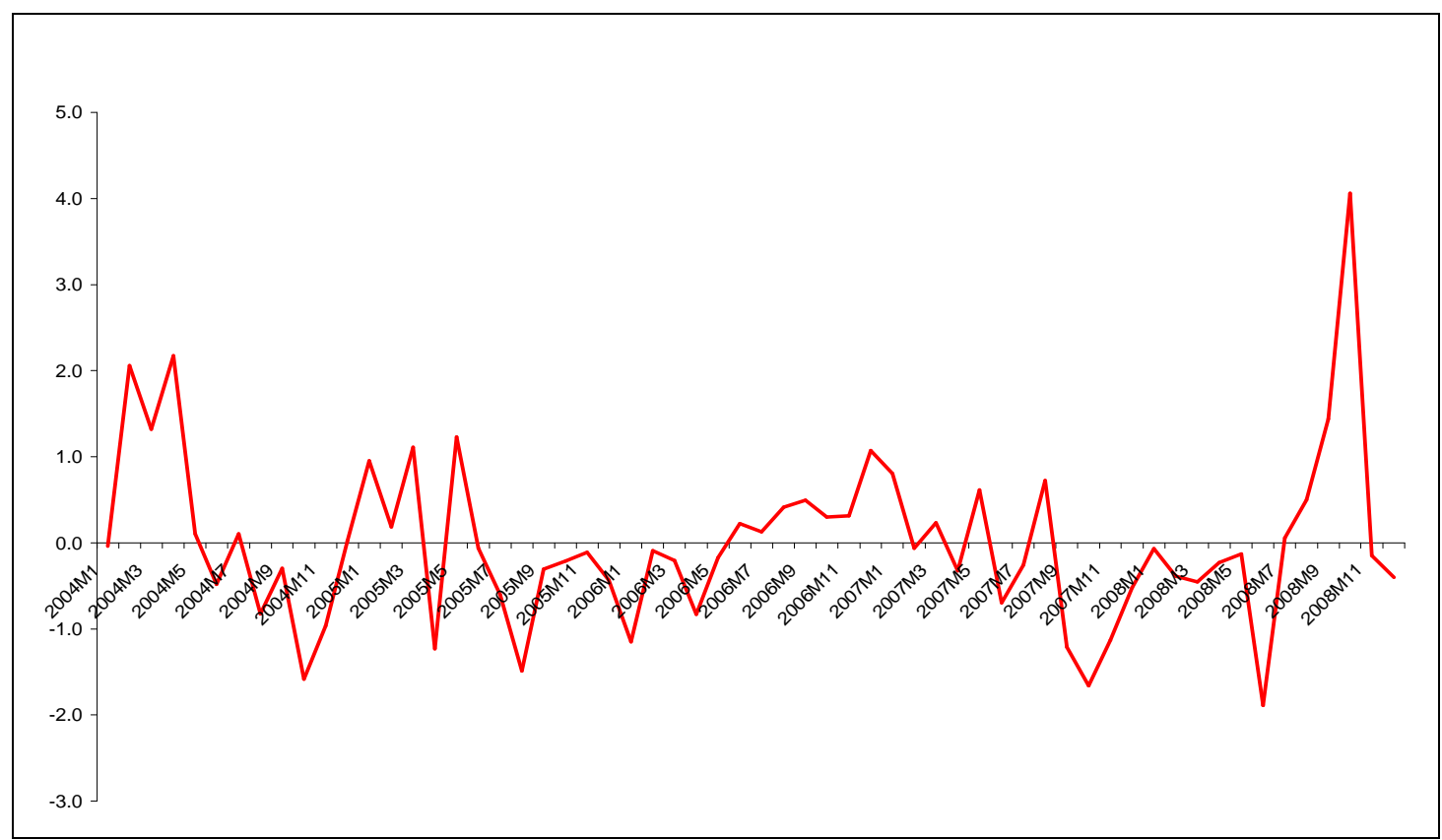

Source: own estimations. 
In the second step, VAR models are estimated at the individual country level. They include a global variable, the regional factor and the respective exchange rate. To obtain some insights on the robustness of the results, the global variable is measured, inter alia, by the gold price, the oil price, and the evolution in international stock markets. As a rule, the SB information criterion recommends a lag order of 1 throughout the specifications. Global, regional and idiosyncratic shocks are identified using the triangular structure outlined above, and the relative importance of these shocks to explain forecast errors of exchange rates is assessed by a variance decomposition exercise, see Table 1 for the results.

Although the results show a quite heterogeneous pattern, more or less, some similarities emerge. First, the results are quite different over the two subperiods. Hence, an analysis for the entire period would be largely inappropriate. More general, this finding points to the fact that empirical work for the CIS countries should take instabilities into account, as the countries are heavily in a period of transition. Second, the relevance of regional shocks seems to have decreased over the recent period. While the impact shows a drastic reduction in Azerbaijan, Kazakhstan, Kyrgyzstan, and Moldova, the decline has been only modest in the Ukraine. The only exception from the rule is the Russian economy, where CIS shocks have gained importance. This could be, however, also traced to the construction of the regional factor, where the Russian economy receives the largest weight. Third, global shocks have become more relevant to explain exchange rate movements, (most importantly in the model Russia when the Dow Jones industrial Index is used), apart from a few exceptions. This reflects a higher integration in the world economy in the second subsample, implying that many CIS countries have become more vulnerable to external shocks. 
Table 1: Decomposition of variance of forecasting errors after 12 quarters A. Global factor is proxied by the oil price

\begin{tabular}{lrccccc}
\hline & \multicolumn{2}{c}{ World } & \multicolumn{2}{c}{ Regional } & \multicolumn{2}{c}{ Idiosyncratic } \\
& $1999-2003$ & $2004-2008$ & $1999-2003$ & $2004-2008$ & $1999-2003$ & $2004-2008$ \\
\hline Azerbaijan & 10.1 & 69.9 & 18.8 & 4.9 & 71.1 & 25.2 \\
Kazakhstan & 1.7 & 25.6 & 53.6 & 10.2 & 44.6 & 64.2 \\
Kyrgyzstan & 3.7 & 36.9 & 48.0 & 31.9 & 48.3 & 31.2 \\
Moldova & 0.0 & 12.8 & 14.6 & 1.1 & 85.4 & 86.1 \\
Russia & 2.7 & 21.0 & 28.4 & 34.2 & 68.9 & 44.8 \\
Ukraine & 13.8 & 7.9 & 23.0 & 29.2 & 63.2 & 62.9 \\
\hline
\end{tabular}

\section{B. Global factor is proxied by the gold price}

\begin{tabular}{lcccccc}
\hline & \multicolumn{2}{c}{ World } & \multicolumn{2}{c}{ Regional } & \multicolumn{2}{c}{ Idiosyncratic } \\
Gold price & $1999-2003$ & $2004-2008$ & $1999-2003$ & $2004-2008$ & $1999-2003$ & $2004-2008$ \\
\hline Azerbaijan & 1.6 & 8.9 & 18.3 & 18.0 & 80.1 & 73.1 \\
Kazakhstan & 0.6 & 46.0 & 55.5 & 14.4 & 43.9 & 39.6 \\
Kyrgyzstan & 50.1 & 27.9 & 26.5 & 45.3 & 23.4 & 26.8 \\
Moldova & 15.7 & 16.9 & 12.3 & 0.8 & 72.0 & 82.3 \\
Russia & 12.6 & 2.4 & 23.9 & 32.1 & 63.5 & 65.5 \\
Ukraine & 0.3 & 4.2 & 24.0 & 32.2 & 75.7 & 63.6 \\
\hline
\end{tabular}

\section{B. Global factor is proxied by the Dow Jones industrial index}

\begin{tabular}{lrccccc}
\hline & \multicolumn{2}{c}{ World } & \multicolumn{2}{c}{ Regional } & \multicolumn{2}{c}{ Idiosyncratic } \\
& $1999-2003$ & $2004-2008$ & $1999-2003$ & $2004-2008$ & $1999-2003$ & $2004-2008$ \\
\hline Azerbaijan & 2.7 & 1.8 & 16.8 & 13.7 & 80.5 & 84.5 \\
Kazakhstan & 0.3 & 18.4 & 54.6 & 12.9 & 45.1 & 68.7 \\
Kyrgyzstan & 32.6 & 67.0 & 34.6 & 15.9 & 32.8 & 17.1 \\
Moldova & 11.6 & 38.8 & 15.6 & 1.4 & 72.8 & 59.8 \\
Russia & 0.3 & 80.8 & 29.3 & 11.0 & 70.4 & 8.2 \\
Ukraine & 4.0 & 28.6 & 25.1 & 24.7 & 70.9 & 46.7 \\
\hline
\end{tabular}

Source: Own Estimations.

Finally, we try to quantify the effect of the financial crisis which hit the world economy in September 2008.

We use estimated FVAR models for the estimation of structural shocks using the standard Choleski decomposition. Figure 3 presents the results for our preferred FVAR specification with global developments being proxied by the oil prices. 3 We can see that all CIS countries experienced a large global shock after the financial crisis. The results show that increasing impact of the world financial crisis on the CIS countries during the last quarter of 2008.

\footnotetext{
${ }^{3}$ Table 1 shows that this specification yields in average the highest share variance of forecasting errors (after 12 quarters) explained by world shocks. Further results are available upon request from authors.
} 
Figure 3: World Shocks in selected CIS countries, 2004-2008
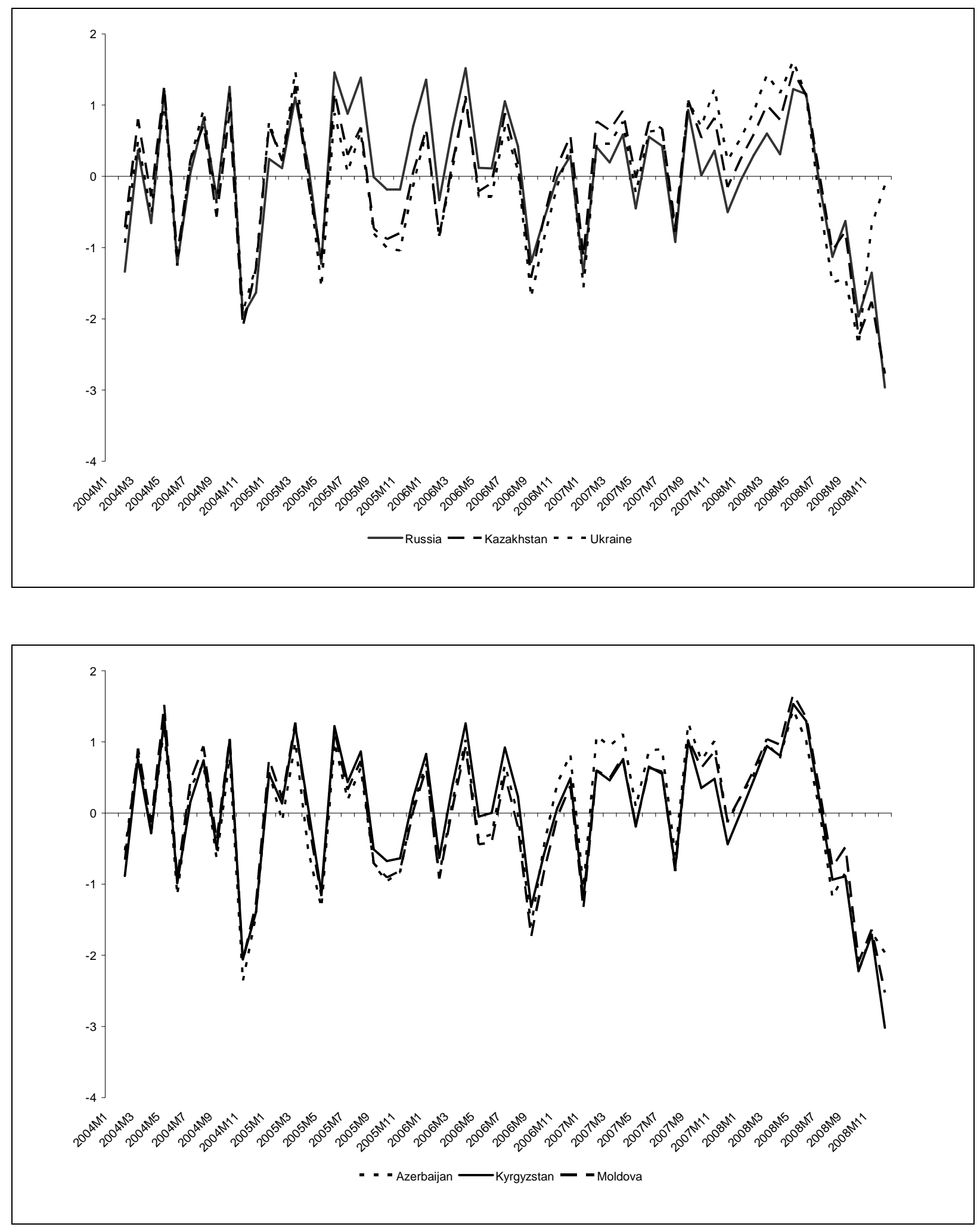

Note: Global financial market is proxied by oil price development.

Source: own estimations. 


\section{Conclusion}

From an external perspective, the economic development of the CIS countries is expected to be dominated by the Russian economy, which represents the largest market in the region. Surprisingly, this was not found in the earlier studies, which looked either at synchronization of business cycles or the degree of financial integration between the CIS countries.

We address this issue with means of FAVAR models, and present the first analysis of this kind for the CIS countries. We decompose exchange rate movements to global, regional and idiosyncratic shocks for two periods: 1999 to 2003 and 2004 to 2008. Our results confirm the previous finding that the regional shocks do not account for a significant share of exchange rate variance in the CIS economies. Moreover, we can see that the importance of the regional factor has declined between both subperiods.

In turn, our results show that global shocks, while still accounting for only a minor share of exchange rate movements in all economies, tend to gain importance. The financial crisis since September 2008 has been playing an important role in this process. This is especially true for estimations where global shocks were included by the development of oil prices. Indeed, global shocks played increasingly important at the end of 2008. As a result, the financial crisis increased the vulnerability of CIS countries.

The CIS countries are still very different especially with regard to the size of idiosyncratic shocks in their economies. We confirm that country-specific factors were the major determinant of exchange rate variance in the early period (1999-2003). Also now, the idiosyncratic shocks are important especially in Ukraine, Russia, Azerbaijan, and Moldova. The Kazakh economy stands out with a comparably more balanced structure of global, regional and idiosyncratic shocks in its economy. 


\section{Rerefences}

Bai, J., Ng, S. (2002), Determining the number of factors in approximate factor models, Econometrica 70, pp. 191-221.

Borkó, Tamás (2007), The Suspicion of Dutch Disease in Russia and the Ability of the Government to Counteract. Working Paper No. 35, ICEG European Center, Budapest.

Chaplygin, Vladimir, Hughes Andrew J. and Christian R. Richter (2006), 'Monetary Integration in the ExSoviet Union: a "Union of Four”, Economics of Transition, 14 (1), pp. 47-68.

Clarida, Richard and Jordi Galí (1994), 'Sources of Real Exchange-Rate Fluctuations: How Important are Nominal Shocks?' Carnegie-Rochester Conference Series on Public Policy 41(1), 1-56.

Dibooglu, Selahattin and Ali M. Kutan (2001), 'Sources of Real Exchange Rate Fluctuations in Transition Economies: The Case of Poland and Hungary.' Journal of Comparative Economics 29(2), pp. 257-275.

Égert, Balázs and Carol Leonard (2008), 'Dutch Disease Scare in Kazakhstan: Is it real?’ Open Economies Review, 19(2), pp. 147-165.

Fidrmuc, Jarko and Jan Fidrmuc (2003), 'Disintegration and Trade', Review of International Economies, 11, pp. 811-829.

Fungáčová, Zuzana and Laura Solanko (2008) Risk Taking by Russian Banks: Do Location, Ownership And Size Matter? BOFIT Discussion Paper No. 21, Bank of Finland, Helsinki.

IMF (2009), Republic of Belarus: Financial System Stability Assessment-Update. Country Report No. 09/30, IMF, Washington.

Juselius, Katarina (2007), The Cointegrated VAR Model: Methodology and Applications. Oxford University Press, Oxford.

Korhonen, Iikka and Paul Wachtel (2006), 'A Note on Exchange Rate Pass-Through in CIS Countries', Research in International Business and Finance 20 (2), pp. 215-226.

Korhonen, Iikka and Aaron Mehrotra (2009), Real Exchange Rate and Oil: Case of Two Large Energy Producers. Mimeo. Bank of Finland, Helsinki.

Koźluk, Tomasz (2008), 'Global and Regional Links Between Stock Markets - the case of Russia and China,’ BOFIT Discussion Paper 4/2008. Bank of Finland, Helsinki.

Odling-Smee, John (2006), 'The IMF and Russia in the 1990s', IMF Staff Papers 53 (1), pp. 151-194. 
Mayes, David G. and Vesa Korhonen (2007), 'The CIS - does the regional hegemon facilitate monetary integration?', BOFIT Discussion Papers No. 16. Bank of Finland, Helsinki.

Oomes, Nienke and Katerina Kalcheva (2007) Diagnosing Dutch disease: Does Russia have the symptoms? BOFIT Discussion Paper No. 7, Bank of Finland, Helsinki.

Polterovich, Victo, Popov, Vladimir and Alexander Tonis (2008). Mechanisms of Resource Curse, Economic Policy and Growth. Working Paper No. WP/2008/000, New Economic School, Moscow.

Schnabl, Gunther (2005), 'International Capital Markets and Exchange Rate Stabilization in the CIS', Journal of Comparative Economics 33(3), pp. 425-440.

Shiells, Clinton R., Pani Marco, and Etibar Jafarov (2005), Is Russia Still Driving Economic Growth? Working Paper WP/05/192, IMF, Washington.

Shleifer, Andrei and Daniel Treisman (2005) 'A Normal Country: Russia After Communism', Journal of Economic Perspectives 19 (1), pp. 151-174.

Sims, C.A., Stock, J.H., Watson, M.W. (1990): Inference in linear time series models with some unit roots, Econometrica 58, pp. 113-144.

Tiffin, Andrew (2008) 'Financial Integration within the CIS' in IMF, Russian Federation: Selected Issues, Country Report No. 08/308, IMF, Washington, pp. 25-43. 